\title{
PENGARUH KEMAMPUAN BERPIKIR LOGIS DAN MOTIVASI BERPRESTASI TERHADAP PRESTASI BELAJAR EKONOMI SISWA KELAS X SMA SWASTA YAYASAN PENDIDIKAN NUR AZIZI TANJUNG MORAWA T.P. 2015/2016
}

\author{
Irwansyah ${ }^{1)}$, Andry Mukti Lubis 2) \\ 1) Fakultas Ekonomi, Universitas Negeri Medan \\ 2) Fakultas Ekonomi, Universitas Negeri Medan
}

\begin{abstract}
Masalah penelitian ini adalah belum maksimalnya prestasi belajar ekonomi siswa. Tujuan penelitian ini adalah untuk mengetahui pengaruh kemampuan berpikir logis dan motivasi berprestasi terhadap prestasi belajar siswa pada mata pelajaran ekonomi kelas XSMA Swasta Yayasan Pendidikan Nur Azizi Tanjung Morawa T.A. 2015/2016. Populasi dalam penelitian ini adalah seluruh kelas X yang berjumlah 170 orang yang terdiri dari 4 kelas. Sampel dalam penelitian ini menggunakan teknik Proportional Random Sampling dengan menggunakan $25 \%$ dari jumlah populasi yaitu sebanyak 42 orang siswa. Teknik yang digunakan dalam pengumpulan data ialah dokumentasi, wawancara, dan tes/kuisioner.Sebelum penelitian dilakukan, terlebih dahulu dilakukan uji validitas dan reliabilitas angket.Analisis yang digunakan dalam penelitian ini adalah analisis regresi linier berganda, uji hipotesis dilakukan dengan uji secara parsial (uji t) dan uji secara simultan (uji F). Kesimpulan dari penelitian ini adalah ada pengaruh yang positif dan signifikan antara kemampuan berpikir logis dan motivasi berprestasi terhadap prestasi belajar ekonomi siswa kelas X SMA Swasta Yayasan Pendidikan Nur Azizi Tanjung Morawa T.A. 2015/2016.
\end{abstract}

Keywords: Kemampuan Berpikir Logis, Motivasi Berprestasi dan Prestasi BelajarEkonomi 


\section{PENDAHULUAN}

Pendidikan adalah sarana utama dalam pembentukan sumber daya manusia yang berkualitas.Pendidikan merupakan kebutuhan manusia sepanjang hidup dan selalu berubah mengikuti perkembangan zaman, teknologi dan budaya masyarakat.Perkembangan dan perubahan pendidikan yang semakin maju menuntut lembaga pendidikan formal atau sekolah dapat membina dan mempersiapkan sumber daya manusia yang berkualitas.

Pencapaian Prestasi Belajar Mata Pelajaran Ekonomi yang diinginkan seseorang sebaiknya perlu mengetahui beberapa hal yang mempengaruhi Prestasi Belajar itu sendiri. Keberhasilan dalam proses belajar mengajar dan dalam upaya peningkatan prestasi belajar dipengaruhi oleh berbagai faktor diantaranya kemampuan berpikir logis dan motivasi berprestasi.

Berpikir merupakan proses berkembangnya ide dan konsep di dalam diri seseorang. Berpikir dapat diartikan sebagai suatu proses otak mengolah dan menterjemahkan informasi (stimulus) yang masuk melalui panca indra kebagian otak sadar atau bawah sadar yang menghasilkan arti dan sejumlah konsep. Berpikir logis adalah suatu proses berpikir dengan menggunakan logika, rasional dan masuk akal. Disamping itu Berpikir Logis dalam memahami pelajaran di sekolah harus ditingkatkan, siswa tidak hanya membaca dan mendengar agar segala hal yang dipelajari dapat dikatan berhasil dalam sekolah. Seorang siswa harus mampu mengolah fenomena-fenomena yang diterima oleh sistem indra hingga dapat memunculkan berbagai pertanyaan yang berkaitan untuk dicari jawabannya. Secara tidak langsung hal ini menuntut siswa untuk meningkatkan kemampuan berpikirnya secara logis dalam menyerap dan menelaah pelajaran yang diterima di sekolah.Sangat penting bagi siswa untuk berpikir logis dan memotivasi diri untuk berprestasi di sekolah.

Untuk itu perlu dikembangkan kembali cara berpikir siswa untuk berpikir secara logis dalam memahami pelajaran dan dengan mengembangkan motivasi dalam belajar agar dapat meningkatkan prestasi belajar pada mata pelajaran ekonomi di sekolah.

Dari uraian yang dikemukakan diatas, maka terlihat jelas pengaruh berpikir logis dan motivasi berprestasi terhadap prestasi belajar yang ingin dicapai siswa pada mata pelajaran ekonomi. Kemampuan berpikir logis menuntut siswa untuk lebih mampu menggunakan prasangka-prasangka yang lebih rasional atau berpikir secara logis. Misalnya dalam pelajaran ekonomi siswa harus mampu menggunakan logika mereka karena dalam ilmu ekonomi tidak ada yang namanya hanya melalui membaca.Tetapi dalam ilmu ekonomi siswa harus mampu menggunakan pikirannya secara logis agar terhindar dari penafsiran-penafsiran yang salah. Sedangkan dengan memiliki motivasi berprestasi yang tinggi akan menjadi pendorong bagi siswa untuk meningkatkan dan mepertahankan prestasi belajarnya.

Namun pada kenyataannya, berdasarkan observasi awal yang dilakukan peneliti, masih terdapat siswa yang memiliki motivasi berprestasi rendah, hal ini terlihat dari ketidakantusiasan siswa mengikuti pelajaran dan menjawab pertanyaan guru ketika proses belajar mengajar berlangsung. Kemudian, ketika peneliti melakukan wawancara pada guru mata pelajaran ekonomi di SMA Swasta Nur Azizi Tanjung Morawa masih banyak siswa siswi kelas $\mathrm{X}$ yang belum mampu mencapai prestasi belajar yang baik, dimana masih banyak siswa yang belum mencapai nilai Kriteria Ketuntasan Minimum (KKM) pada mata pelajaran ekonomi yaitu 70 .

Berdasarkan hasil observasi di SMA Swasta Yayasan Pendidikan Nur Azizi Tanjung Morawa pada tanggal 18 Januari 2016 diperoleh bahwa keterangan prestasi belajar Ekonomi dikelas X kurang memuaskan. Dapat dilihat pada tabel dibawah ini :

Tabel 1

Persentase Kelulusan Siswa Mata Pelajaran Ekonomi Kelas X

\begin{tabular}{|c|c|c|c|c|}
\hline \multirow[b]{2}{*}{ Kelas } & \multirow[b]{2}{*}{$\begin{array}{l}\text { Jumlah } \\
\text { Siswa }\end{array}$} & \multicolumn{2}{|c|}{ Presentase Siswa } & \multirow[b]{2}{*}{ KKM } \\
\hline & & $\begin{array}{l}\text { Mencapai } \\
\text { KKM }\end{array}$ & $\begin{array}{l}\text { Belum } \\
\text { Mencapai } \\
\text { KKM } \\
\end{array}$ & \\
\hline X MIA 1 & 46 Orang & $43 \%$ (20 Orang) & $57 \%$ (26 Orang) & \multirow{5}{*}{70} \\
\hline X MIA 2 & 46 Orang & $41 \%$ (19 Orang) & $59 \%$ (27 Orang) & \\
\hline $\mathrm{X}$ IIS 1 & 40 Orang & $48 \%$ (19 Orang) & $52 \%$ (21 Orang) & \\
\hline $\mathrm{X}$ IIS 2 & 38 Orang & $42 \%$ (16 Orang) & $58 \%$ (22 Orang) & \\
\hline Jumlah & 170 Orang & $44 \%$ (74 Orang) & $56 \%$ (96 Orang) & \\
\hline
\end{tabular}

Berdasarkan tabel diatas terlihat ketuntasan siswa kelas X SMA Swasta Nur Azizi Tanjung Morawa masih rendah, hal ini terbukti dari persentase ketuntasan yang hanya sebesar $44 \%$ 
atau berjumlah 74 orang siswa dari jumlah keseluruhan 170 orang siswa kelas X SMA Swasta Nur Azizi. Hal ini membuktikan bahwa prestasi belajar yang baik masih jauh dari yang diharapkan, karena dari total 170 orang jumlah siswa kelas X masih banyak terdapat siswa yang belum mencapai Kriteria Ketuntasan Minumum (KKM) yaitu sekitar 56\% atau berjumlah 96 orang siswa.

Dari hasil observasi yang diperoleh peneliti pada saat mengamati kegiatan belajar mengajar dikelas pada umumnya siswa terlihat kurang memahami pelajaran ekonomi yang disampaikan guru, hal ini terlihat ketika guru memberikan pertanyaan kepada siswa dan siswa tidak bisa menjawab pertanyaan tersebut dengan benar.Sikap yang dimunculkan juga masih kurang interaktif antara guru dan siswa, hal tersebut terlihat dari interaksi yang kurang baik antara guru dan siswa.Ketika guru berkomunikasi dengan siswa dikelas, siswa tidak merespon dengan baik pertanyaan yang diberikan oleh guru. Jika dibandingkan antara siswa yang aktif dengan yang tidak aktif tentu akan terlihat jelas perbandingannya jika dilihat didalam kelas. Kemudian ketika guru memberikan pertanyaan atau kuis kepada siswa di dalam kelas maka respon yang terlihat masih kurangnya antusias siswa dalam menjawab pertanyaan dan terlihat ketika siswa menjawab pertanyaan yang diberikan oleh guru tersebut seperti tidak menggunakan logika dan terkesan seperti asal menjawab. Hal ini mengindikasikan bahwasanya siswa kurang berpikir secara logis dalam menalar dan memahami pelajaran serta kurang memiliki motivasi berprestasi di dalam proses kegiatan belajar mengajar.

Penyebab inilah yang memicu rendahnya prestasi belajar siswa. Guru telah maksimal dalam memberikan materi pelajaran yang sesuai dengan kurikulum, namun yang terjadi tetap saja masih kurang memuaskan bagi guru dan tentunya sekolah tersebut. Untuk itu perlu adanya sebuah pemikiran untuk memecahkan masalah yang dihadapi guru dan sekolah tersebut, menurut pandangan peneliti ada indikasi kurangnya kemampuan berpikir logis siswa dan motivasi berprestasi siswa yang berimbas pada rendahnya prestasi belajar siswa.

\section{METODE PENELITIAN}

Populasi dalam penelitian ini adalah siswa kelas XSMA Swasta Yayasan Pendidikan Nur Azizi Tanjung Morawa yang berjumlah 170 siswa, sedangkan sampel dalam penelitian ini sejumlah 42 siswa dengan teknik pengambilan sampel proportional random sampling. Variabel dalam penelitian ini adalah Kemampuan Berpikir Logis, Motivasi Berprestasi, dan Prestasi Belajar.

1. Kemampuan Berpikir Logis sadalah proses penggunaan penalaran secara konsisten untuk mengambil sebuah kesimpulan. Permasalahan atau situasi yang melibatkan pemikiran logis mengharapkan struktur, hubungan antara fakta-fakta, dan menghubungkan penalaran yang "bisa dipahami". Adapun indicator dalam tes kemampuan berpikir logis yaitu inferensi, mengenal asumsi, deduksi, interpretasi dan evaluasi argumen.

2. Motivasi Berprestasi adalah suatu dorongan atau keinginan didalam diri siswa untuk mencapai tujuan yaitu keberhasilan yang setinggi mungkin dalam pencapaian prestasi dibidang akademik. Adapun indikator orang yang memiliki motivasi berprestasi yang tinggi yaitu memerlukan umpan balik segera, suka mengambil resiko, memperhitungkan keberhasilan, mandiri dalam belajar, dan menyatu dengan tugas.

3. Prestasi belajar adalah hasil yang telah dicapai berupa nilai dengan melalui proses pembelajaran yang menyangkut kognitif, afektif, dan psikomotorik yang dilakukan selama satu semester, yang pada akhirnya dituangkan kedalam nilai yang berbentuk angka-angka. Angka tersebut merupakan cerminan dari hasil yang dicapai siswa dalam belajar hasilnya dapat dilihat dalam raport.

\section{HASIL DAN PEMBAHASAN}

Hasil penelitian menunjukkan bahwa tingkat kecenderungan kemampuan berpikir logis siswa kelas X SMA Swasta Nur Azizi Tanjung Morawa Tahun Ajaran 2015/2016 sebagian besar pada kategori sedang dengan persentase sebesar $33,33 \%$, sedangkan tingkat kecenderungan motivasi berprestasi dengan persentase $43,55 \%$ berada pada kategori tinggi, dan tingkat kecenderungan prestasi belajar ekonomi berada pada kategori kurang sebesar $30,95 \%$.

Selanjutnya hasil uji hipotesis, Untuk nilai $t_{\text {hitung }}$ kemampuan berpikir logis $\left(\mathrm{X}_{1}\right)$ sebesar 3,051 dan $t_{\text {tabel }} \mathrm{N}=42$ pada taraf signifikan 95\% $(\alpha=0,05)$ adalah 1,683 sehingga $t_{\text {hitung }}>t_{\text {tabel }}(3,051>1,683)$. Berdasarkan kriteria 
pengujian hipotesis maka dapat disimpulkan bahwa $\mathrm{Ha}_{1}$ diterima dan $\mathrm{Ho}_{1}$ ditolak yaitu "Terdapat pengaruh positif dan signifikan antara kemampuan berpikir logis terhadap prestasi belajar ekonomi siswa kelas X SMA Swasta Nur Azizi Tanjung Morawa Tahun Ajaran 2015/2016".

Untuk nilai $t_{\text {hitung }}$ motivasi berprestasi $\left(\mathrm{X}_{2}\right)$ sebesar 2,177 dan $\mathrm{t}_{\text {tabel }} \mathrm{N}=42$ pada taraf signifikan $95 \%(\alpha=0,05)$ adalah 1,683 sehingga $t_{\text {hitung }}>t_{\text {tabel }}(2,177>1,683)$. Berdasarkan kriteria pengujian hipotesis maka dapat disimpulkan bahwa $\mathrm{Ha}_{2}$ diterima dan $\mathrm{Ho}_{2}$ ditolak yaitu "Terdapat pengaruh positif dan signifikan antara motivasi berprestasi terhadap prestasi belajar ekonomi siswa kelas X SMA Swasta Nur Azizi Tanjung Morawa Tahun Ajaran 2015/2016".

Hasil uji $\mathrm{F}$ yaitu nilai $\mathrm{F}_{\text {hitung }}=207,273$ yang selanjutnya dibandingkan dengan $F_{\text {tabel }}$ pada taraf signifikan $95 \%(\alpha=0,05)$ dan $\mathrm{dk}=42$ $-3=39$ yaitu 3,24 . Nilai $F_{\text {hitung }}>F_{\text {tabel }}(207,273$ $>3,24)$ dan nilai Sig $<\alpha=0,05$. Hal ini berarti bahwa $\mathrm{Ha}_{3}$ diterima dan $\mathrm{Ho}_{3}$ ditolak, sehingga dapat disimpulkan bahwa "Terdapat pengaruh yang positif dan signifikan secara simultan antara kemampuan berpikir logis dan motivasi berprestasi terhadap prestasi belajar ekonomi siswa kelas X SMA Swasta Nur Azizi Tanjung Morawa Tahun Ajaran 2015/2016".

Selain itu dari perhitungan determinasi juga diperoleh nilai R Squaresebesar 0,914 yang berarti 91,4\% prestasi belajar ekonomi siswa di Kelas X SMA Swasta Nur Azizi Tanjung Morawa secara bersama-sama dipengaruhi oleh kemampuan berpikir logis dan motivasi berprestasi siswa, sedangkan $8,6 \%$ dipengaruhi oleh faktor lain yang tidak di teliti dalam penelitian ini. Berdasarkan presentase tersebut dapat disimpulkan bahwa kemampuan berpikir logis dan motivasi berprestasi siswa berpengaruh positif dan signifikan terhadap prestasi belajar ekonomi siswa Kelas X SMA Swasta Nur Azizi Tanjung Morawa.

\section{KESIMPULAN}

Berdasarkan hasil penelitian ini secara keseluruhan dapat ditarik kesimpulan bahwa secara parsial menunjukkan bahwa terdapat pengaruh yang positif dan signifikan antara kemampuan berpikir logis terhadap prestasi belajar ekonomi siswa kelas X SMA Swasta Nur Azizi Tanjung Morawa Tahun Ajaran 2015/2016. Hal ini berarti siswa yang memiliki kemampuan berpikir logis yang tinggi akan memperoleh prestasi belajar yang tinggi pula pada mata pelajaran ekonomi. Dan hasil hipotesis secara parsial menunjukkan bahwa terdapat pengaruh yang positif dan signifikan antara motivasi berprestasi terhadap prestasi belajar ekonomi siswa kelas X SMA Swasta Nur Azizi Tanjung Morawa Tahun Ajaran 2015/2016. Hal ini berarti siswa yang memiliki motivasi berprestasi yang tinggi akan memperoleh prestasi belajar yang tinggi pula pada mata pelajaran ekonomi. Hasil uji hipotesis secara simultan menunjukkan bahwa terdapat pengaruh yang positif dan signifikan antara kemampuan berpikir logis dan motivasi berprestasi terhadap prestasi belajar ekonomi siswa kelas X SMA Swasta Nur Azizi Tanjung Morawa Tahun Ajaran 2015/2016, yang di tunjukan dari hasil uji $\mathrm{F}$ (simultan)

\section{REFERENSI}

Arikunto, Suharsimi. 2006. Prosedur Penelitian Secara Pendekatan Praktik. Jakarta : PT.Rineka Cipta

Bochenski, Pengertian Dan Definisi Berpikir (Thinking) Menurut Ahli, http://ariplie.blogspot.co.id/2015/04/pe ngertian-dan-definisiberpikir.html(Diakses 23 Maret 2016)

Fakultas Ekonomi. 2016. Pedoman Penulisan Skripsi Mahasiswa Program S1. Universitas Negeri Medan

Hamdani. 2010. Strategi Belajar Mengajar. Bandung : Pustaka Setia

Hamid, Hamdani. 2013. Pengembangan Sistem Pendidikan di Indonesia. Bandung: CV Pustaka Setia

Karomani. 2012. Logika. Yogyakarta : Graha Ilmu

Khalimi.2011. Logika Teori dan Terapan.Jakarta : Gaung Persada (GP) Press.

Kuswana, Wowo Sunaryo. 2013. Taksonomi Berpikir. Bandung : PT Remaja Rosdakarya

Latif, Mukhtar. 2014. Orientasi Ke Arah Pemahaman Filsafat Ilmu. Jakarta : Kencana

McClelland, D.C. (1987). Human motivation. New York: The Press Syndicate of The University of Chambridge. (http://repository.usu.ac.id/bitstream/12 3456789/1938/3/06010309.pdf.txt)(Diak ses 23 Maret 2016) 
Ngatiqoh, Siti, dkk. 2012. Pengaruh Motivasi Berprestasi dan Kreativitas Berpikir terhadap Prestasi Belajar IPA (Fisika) Kelas VIII SMP Negeri se-Kabupaten Purworejo Tahun Pelajaran 2011/2012.Jurnal Radiasi Vol.1.No.1. ISSN: 2301-6111 Pendidikan Fisika UMP

Purwanto, Andik. 2012. Kemampuan Berpikir Logis Siswa SMA N 8 Kota Bengkulu Dengan Menerapkan Model Inkuiri Terbimbing Dalam Pembelajaran Fisika. ISSN :1412-3617

Putri, Gusnita Roza, dkk. "Hubungan Kemampuan Berpikir Logis Dengan Menulis Karangan Argumentasi Siswa Kelas X SMA Negeri 1 Rao Kabupaten Pasaman”. Jurnal Pendidikan Bahasa dan Sastra Indonesia, Vol. 1 No.1 September 2012: Seri A 1-86

Rasdini, Ari. (2011). Kontribusi Kematangan Emosional, Motivasi Berprestasi Dan Konsep Diri Terhadap Prestasi Belajar KDM. Jurnal Ilmiah Pendidikan dan Pembelajaran Pps Universitas Pendidikan Ganesha ISSN 1858 - 4543

Rusyna, Adun. 2014. Keterampilan Berpikir. Yogyakarta : Penerbit Ombak

Sardiman. 2009. Interaksi dan Motivasi Belajar Mengajar. Jakarta : Raja Grafindo Persada

Setiawan, Ananda. 2015. "Hubungan Berfikir Kreatif Dan Motivasi Berprestasi Dengan Prestasi Belajar Mahasiswa Pendidikan Ekonomi Fakultas Ekonomi Universitas Negeri Medan Angkatan 2014'. Skripsi FE Unimed.

Slameto. 2010. Belajar dan Faktor-faktor yang Mempengaruhi. Jakarta: PT Rineka Cipta

Sugiyono. 2012. Metode Penelitian Pendidikan Pendekatan Kuantitatif, Kualitatif, dan $R \& D$. Bandung : Alfabeta

Surajiyo, dkk. 2007. Dasar-Dasar Logika. Jakarta : PT Bumi Aksara

Syah, Muhibbin. 2012. Psikologi Belajar. Jakarta: PT Raja Grafindo Persada

Tumanggor, Rudianto. 2015. "Hubungan Minat Baca Dan Kemampuan Berpikir Logis Dengan Hasil Belajar Ekonomi Siswa Kelas X SMAN 2 Sidikalang”. Skripsi, FE Unimed : Medan

Usdiyana, Dian, dkk. 2009. Meningkatkan Kemampuan Berpikir Logis Siswa SMP
Melalui Pembelajaran Matematika Realistik.ISSN : 1412-017

Widodo,S. 2004. Psikologi Belajar. Jakarta : Rineka Cipta. 